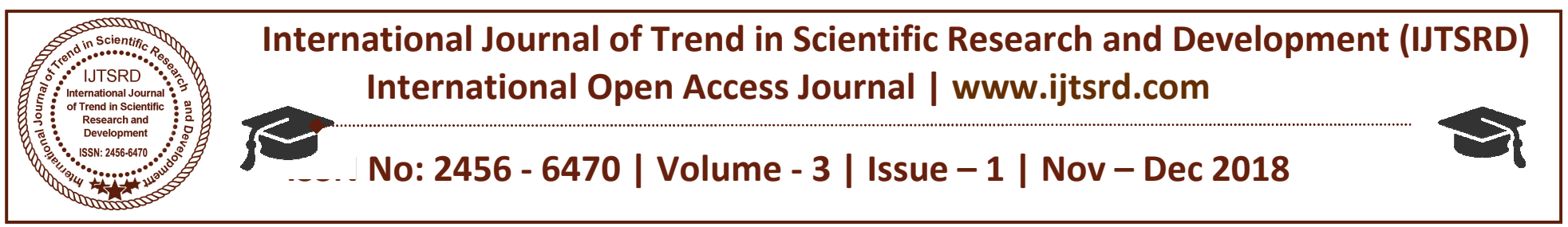

\title{
The Importance of Learning English in Today World
}

\author{
Rajathurai Nishanthi \\ Ph.D Research Scholar, Department of Sociology, \\ Bharathidasan University, Tiruchirappalli, Tamil Nadu, India
}

\begin{abstract}
In today's global world, the importance of English cannot be denied and ignored since English is the greatest common language spoken universally. To learn English requires constant practice and patience. The kind of feeling that succeeds among students is that it is not possible to achieve fluency or mastery over the English language. This kind of tendency prevents students from learning English. Most of the students study English from the examination point of view, so they are not able to produce even a single sentence without the grammatical error. Furthermore, sufficient practice is not given to students to learn a language. Knowledge of English is necessary if one wants to come up in life. It is the major window of the modern world. This is all the more true where the advanced countries have opened their doors for recruiting technically qualified persons. Only those who have a command over the English language are given a job.
\end{abstract}

KEY WORDS: English, greatest common language, major window of the modern world

\section{INTRODUCTION}

Language is our significant source of communication. It's the way through which we share our ideas, feelings, views, and thoughts with others. Language separates us from animals and makes us human. There are thousands of languages in this world. Each Country has their peculiar nationwide language in addition to a multiplicity of local languages spoken and understood by their people in different regions. Some languages are spoken by millions of people, others by only a few thousand.

In today's global world, the importance of English cannot be denied and ignored since English is the greatest common language spoken universally. With

the help of emerging technology, English has been playing the main part in several sectors including medicine, engineering, and education, etc. English is a vital language for all kinds of professional and personal goals.

\section{HISTORICAL BACKGROUND OF ENGLISH:}

English was initially the language of England, but over the historical efforts of the British Empire, it has developed the primary or secondary language of numerous former British colonies such as the United States, Canada, Australia, Sri Lanka, and India etc. Currently, English is the primary language of not only countries actively touched by British imperialism, but also many business and cultural spheres dominated by those countries. In another word even outside of countries like the U.S. and the U.K., many people can speak and understand English It is the language of Hollywood and the language of international banking and business. As such, it is a useful and even necessary language to know. An estimated 1 billion people worldwide speak English On top of this, 67 countries have English as their official language and there are 27 countries that have English as their secondary official language. Why is this? It all has to do with history and the key is the British Empire.

\section{SIGNIFICANCE OF THE STUDY}

English is the most commonly spoken language in the world. One out of five people can speak or at least understand English. It is also called the major window on the world, which means that English gives us the view of the various progress taking place in the world. Majority of Sri Lanka and Indian students, particularly from rural area considers the word of English as a magical and a mystical word. 
The moment they hear something in English they start to feeling discomfort. Twelve years of school study and three years of college study do not make students mastery over English. While they are in schools as well as colleges English is not taught properly. The majority of the students are addressed from rural areas, the bilingual method is adopted in language classes. This method helps only to slow learners to some extent. Moreover, this act reduces the real learning process as a whole.

To learn English requires constant practice and patience. The kind of feeling that succeeds among students is that it is not possible to achieve fluency or mastery over the English language. This kind of tendency prevents students from learning English. Most of the students study English from the examination point of view, so they are not able to produce even a single sentence without the grammatical error. Furthermore, sufficient practice is not given to students to learn a language.

Knowledge of English is necessary if one wants to come up in life. It is the major window of the modern world. This is all the more true where the advanced countries have opened their doors for recruiting technically qualified persons. Only those who have a command over the English language are given a job.

\section{REASONS TO LEARNING ENGLISH}

There are several factors that make the English language essential to communication in our current time.

\section{English is the International Common Tongue}

First of all, English is the most common foreign language. This means that two people who come from different countries (for example, a Mexican and a Sri Lankan) usually use English as a common language to communicate. That's why everyone needs to learn the language in order to get in touch on an international level. Speaking it will help you communicate with people from countries all over the world, not just English-speaking ones.

The British Council projects that by 2020 two billion people in the world will be studying English. Learning English is important as it enables you to communicate easily with your fellow global citizens.

\section{Education}

English is also necessary for the field of education. In many countries, children are taught and encouraged to learn English as a second language. Even in countries where it is not an official language. We will find many curriculums in science, engineering and higher education filed are written in English. Because it is the dominant language in the sciences, most of the research and studies you find in any given scientific field will be written in it as well.

At the university level, students in many countries study almost all their subjects in English in order to make the material more accessible to international students. English remains a major medium of instruction in schools, universities. There are large numbers of books that are written in the English language. English literature is vast and rich. Many of the latest scientific discoveries are documented in English.

\section{The Internet and Press}

On the Internet, the majority of websites are written and created in English. Even sites in other languages often give you the option to translate the site. It's the primary language of the press: more newspapers and books are written in English than in any other language, and no matter where in the world you are, you will find some of these books and newspapers available. In fact, because it is so dominant in international communication, you will find more information regarding nearly every subject if you can speak this language.

According to a report by Education First, English is the language of the internet. An estimated 565 million people use the internet every day, and an estimated 52 percent of the world's most visited websites are displayed in the English language.

Learning English is important as it gives access to over half the content on the internet. Knowing how to read English will allow access to billions of pages of information which may not be otherwise available.

\section{Resources Make Learning English Easy}

Although many people think that it is very difficult and confusing, English is actually the easiest language of the world to learn because there are so many resources available. As soon as you decide you want to learn, there are thousands of resources on the Internet and in bookstores.

\section{Travel and Business}

With good understanding and communication in English, we can travel around the globe. Because it is 
the international language for foreigners, it's easy to get assistance and help in every part of the world. We can test it by online travel. Any travel booking site we can find will have English as a booking option.

English skills will also help us in any business venture you choose to follow. If we visit some offices, companies, governmental organizations, or even math or engineering companies, we will see the importance of English. Any big company will hire their professional staff after getting to know whether the people they are hiring are good at English or not. Companies who want to function at an international level only consider their staff well educated if they are good English speakers, writers, and readers.

English is the dominant business language and it has become almost a necessity for people to speak English if they are to enter a global workforce. Research from all over the world shows that cross-border business communication is most often conducted in English and many international companies expect employees to be fluent in English.

Global companies such as Airbus, Daimler-Chrysler, Fast Retailing, Nokia, Renault, Samsung, SAP, Technicolor, and Microsoft in Beijing, have mandated English as their official corporate language. In addition, in 2010 the company Rakuten, a Japanese cross between Amazon and Ebay, made it mandatory for their 7,100 Japanese employees to be able to speak English.

\section{The Language of Hollywood/ Most movies are in English}

Everyone knows that Hollywood is in the United States and that the biggest television and music industries in the world are based there. As I mentioned above, TV and movies are a great way to practice your English once you start learning. What's more, knowing English opens up thousands of movies, television shows, and games for your enjoyment. If you want to one day work in the entertainment industry, English is even more essential.

Those who are still unaware of the importance of English should start learning it, as a time will come when everything will be understood, spoken and written in English. In a lot of ways, that time is already here. Go ahead, watch some media, and get an idea of the language. You won't be disappointed.

\section{Speaking English gives to Access to a World of Entertainment}

Many of the world's top films, books and music are published and produced in English. Therefore, by learning English we will have access to a great wealth of entertainment and will be able to have a greater cultural understanding. If we speak English, we won't need to rely on translations and subtitles anymore to enjoy your favourite books, songs, films, and TV shows.

\section{It helps to understand other languages}

English has a long and fascinating history that spans wars, invasions, and influences from around the globe. Cultures that have helped shape modern English include Romans, Vikings and the French. For this reason, it's a hybrid language comprised of Latin, Germanic and Romance elements.

\section{We can say things in a hundred different ways}

One of English's best assets is its flexibility. We can often find many different ways to explain the same thing thanks to its wide range of vocabulary. It's said to have well over 750,000 words (depending a bit on how we count - some generous estimates put that number at 1 million) and is adding new ones every year as mentioned in the article about the history of English language.

\section{It's really flexible}

Non-native English speakers who learn it as a second language often comment on how many ways there are to say things. That's because English doesn't discriminate - you can use it however you like. Countries like Singapore have taken this concept to heart, inventing an entirely new type of English called 'Singlish' that has absorbed facets of other languages like Chinese and Malay.

\section{It's easy to learn}

This is generally accepted that English isn't the most taxing language to get to grips with. The vocabulary is simple to grasp and it has developed throughout different languages regarding its evolution that is explained in the article about the history of the English language. Therefore, many speakers of those languages can see where concepts in English originated from and fast adapt to understand the basics of English. 


\section{CONCLUSION:}

English is one of the most used and dominating languages in the world. This is having its impact on every field of work. Undoubtedly, English play a much greater role in the world that it is inevitable for people to ignore it fully. It has a bright future, it helps connect us in a global world, and it can also help us in our personal and professional life. Although learning English can be challenging and time-consuming, we can see that it is also very valuable to learn and can create many opportunities.

\section{REFERENCE}

1. Bolinger, Dwight. (1968). Aspects of language. New York: Harcourt, Brace \& World Inc. Bose, M.N.K. (2007). A text book of English language ndteaching (ELT) for Indian students (2 Ed.). Chennai: New Century Book House.

2. Jalaluddin, NorHashimah\& et al. (2009). "Linguistics and environment in English language learning: Towards the development of quality human capital". European Journalof Social Sciences, 9(4), 27-642, from jccc@infonet.in, retrieved on March 3, 2011.
3. James, Cherian. (1996). "An analysis of selected problems that confront students and teachers of second language". Dissertation Abstracts International, 57(9), 3857-A.

4. Nishino, T., \& Watanabe, M. (2008). Communication-oriented policies versus classroom realities in Japan. TESOL Quarterly, 24(1), 133-138.

5. Nunan, D. (2003). The impact of English as a global language on educational policies and practices in the Asia-Pacific region. TESOL Quarterly, 37 (4), 589-613.

6. https://www.british-study.com/adults/10-reasonsto-learn-english.php

7. https://www.elc-schools.com/blog/4-reasons-whylearning-english-is-so-important/

8. http://toeflgencligi.blogspot.com/2008/11/importa nce-of-english.html

9. https://owlcation.com/humanities/importanceofen glishlanguages 